\title{
2016 Canadian History of Education Association (CHEA) Award Recipients
}

The Canadian History of Education Association awarded its biennial publication prizes at its 2016 conference held in Waterloo, Ontario, from October 27-30. The awards cover the period from 2014-2016.

L'Association canadienne d'histoire de l'éducation a décerné ses prix bisannuels lors de son congrès tenu à Waterloo, Ontario, du 27 au 30 octobre 2016. Ces récompenses couvrent les années 2014-2016.

\section{Distinguished Contribution Award}

Paul Axelrod, Professor Emeritus, York University

Alison Prentice, Professor Emeritus, University of Toronto

J. Donald Wilson, Professor Emeritus, University of British Columbia

\section{CHEA Founders' Prize Recipients}

\section{Cathy James Memorial Dissertation Prize}

Winner:

Griffith, Jane. News from School: Language, Time and Place in the Newspapers of 1890s Indian Boarding Schools in Canada. Unpublished doctoral dissertation, York University, 2015.

Runners Up:

Kmiec, Patricia. More Than Sunday's Lessons: Sunday School Education in Upper Canada 1811-1850. Unpublished doctoral dissertation, OISE-University of Toronto, 2015.

Cole, Josh. Children, Liberalism and Utopia: Education, Hall-Dennis and Modernity in Ontario's Long 1960s. Unpublished doctoral dissertation, Queen's University, 2015.

\section{English-language Article/Original Chapter Prize}

Osborne, Ken. “'One Great Epic Unfolding': H.G. Wells and the Interwar Debate on the Teaching of History." Historical Studies in Education/Revue d'histoire de l'éducation 26, no. 2 (Fall, 2014): 1-29.

\section{French-language Article/Original Chapter Prize}

Dufour, Andrée. "L'école normale Saint-Joseph de Hull, 1909-1968: 60 ans de formation d'institutrices." Revue d'histoire de l'éducation/Historical Studies in Education 26, no. 2 (Fall, 2014): 48-70.

\section{French-language Book/Anthology Prize}

Belliveau, Joel. Le "moment 68" et la réinvention de l'Acadie. Ottawa: Les presses de l'Université d'Ottawa, 2014. 
150 Historical Studies in Education/Revue d'histoire de l'éducation

\section{English-language Book/Anthology Prize (tie)}

Gidney, Catherine. Tending the Student Body: Youth, Health, and the Modern University. Toronto: University of Toronto Press, 2015.

Di Mascio, Anthony. The Idea of Popular Schooling in Upper Canada: Print Culture, Public Discourse, and the Demand for Education. Montreal: McGill-Queen's University Press, 2012. 